$$
\begin{aligned}
& \text { マクロファージのプラスミノーゲン・アクチベー } \\
& \text { ター分沁に及ぼすリンフォカインの刺激効果 }
\end{aligned}
$$

東海林真司* 伊崎 誠一* 瀬川 郁雄* 日比野利彦*

\title{
Plasminogen activator secreted from macrophages stimulated by lymphokines
}

\author{
Shinji TOKAIRIN*, Seiichi IZAKI*, Ikuo SEGAWA* \\ and Toshihiko HIBINO*
}

\author{
Key words: plasminogen activator, inflammation, \\ macrophage, lymphokines, $\gamma$-interferon
}

In our previous study, we have demonstrated that plasminogen activators (PAs) with $\mathrm{Mr}=24,000$ and $\mathrm{Mr}=48,000$ play an important role in tissue fibrinolysis during the development of hypersensitivity granulomas. In order to investigate the cellular source of these PAs, we cultured mouse peritoneal macrophages in different conditions. C57BL/6N mice were used with or without infection by Mycobacterium lepraemurium. Antigen stimulated peritoneal exudate macrophages were obtained by intraperitoneal injection of sonicated M. lepraemurium to the infected mice. PA activity in conditioned media was assayed by using twostage colorimetric method and electrophoretic enzymography. Resident peritoneal macrophages secreted $\mathrm{PA}$ with $\mathrm{Mr}=48,000$. However antigen stimulated peritoneal exudate macrophages secreted a high activity of $\mathrm{PA}$ with $\mathrm{Mr}=24,000$ in addition to $\mathrm{Mr}=48,000$. In order to investigate secretion mechanism, in vitro stimulation of macrophages was carried out by lymphokines which were obtained from culture supernatants of splenic cells exposed with antigen or splenic $\mathrm{T}$ cells with Concanavalin A. The results clearly demonstrated that macrophages became secretable of $\mathrm{PA}$ with $\mathrm{Mr}=24,000$ by lymphokine stimulation. Further experiments showed that the effect of lymphokine to induce secretion of PA was par-

* 岩手医科大学医学部皮虐科学講座 [T020 盛岡市内丸 19-1], The Depertment of Dermatology, School of Medicine, Iwate Medical University, Morioka, Japan. 受付: 1987.7.16. 受理 : 1987.9.9. 
tially represented by $\gamma$-Interferon. These data indicated that the immunological stimulation induced macrophages to secrete PA, the molecular weight of which was altered from resident macrophages.

\section{目 的}

鼠らいを用いた慢性肉芽腫性炎の研究に扔い て，われわれはこれまで肉芽腫抽出液中に，分 子量 48,000 抢よび 24,000 のプラスミノーゲン ・アクチベーター (PA)が出現することを報告 している1'. 今回，常在性腹腔マクロファージ (Resident peritoneal macrophages) あるいは 腹腔浸出マクロファージ (Peritoneal exudate macrophages）を招の招の培養し，その培養上 清中に出現するプラスミノーゲン・アクチベー ター (PA) 活性を測定し，さらには分子量につ いて比較検討した。 加えて, 常在性腹腔マク口 ファージ培養液中に，リンフォカインあるいは マウスガンマインターフェロン(mouse $\gamma$-IFN) のような免疫学的刺激を加觉る実験を行ないマ クロファージ PA の分泌に及ぼす影響について 検討した.

\section{I. 方 法}

1. マクロファージの培養と刺激実験

非感染マウスから常在性腹腔細胞を採取し た2). 鼠らい菌感染マウスに, 超音波処理鼠ら い菌抗原懸濁液を腹腔内注射し ${ }^{3)} ， 4$ 日後に腹 腔浸出細胞を採取した.

これらの細胞を，抢の括の $3 \times 10^{5}$ 個 $/ \mathrm{cm}^{2}$ と なるように $10 \%$ 熱処理牛胎児血清 (10\% HTFCS）を含むダルベッコ変法イーグル培養液 (DMEM) 中で 4 時間培養した. 非付着細胞 を, 食塩加リン酸緩衝液にて 3 回洗い流してマ クロファージを得た2)。さらに 24 時間 DMEM $+10 \%$ HT-FCS 中にて培養し, その後 PA 活 性測定のため24時間毎に HT-FCS を含まない DMEM と交換した。 プラスチック付着細胞の 同定のために，非特異的エステラーゼ染色 ${ }^{4)}$ 和 よび Latex 貪食試験 ${ }^{5}$ を行った.

In vitro でのマクロファージに対する免疫学 的刺激実験のために，リンフォカインの調整を
行った. 鼠らい菌抗原を混入した感染マウス脾 細胞6), あるいはレクチンとして $5 \mu \mathrm{g} / \mathrm{m} l$ コン カナバリン A (Con A) を混入した非感染マウ ス脾蔵下細胞を，抒の括の $37^{\circ} \mathrm{C} 4$ 時間 $5 \%$ HT-FCS を含む RPMI 培養液中で培養し抗原 刺激リンフォカイン (Ag-Lymphokine) あるい はレクチン刺激リンフォカイン (Con A-Lmphokine）を得た。脾臓 $\mathrm{T}$ 細胞は，ナイロンウー ルカラム法7を用いて調整した。 これらのリン フォカインを，30\% vol/vol の濃度で常在性腹 腔マクロファージの培養液中に培養開始より 24 時間混入した。 あるいは常在性腹腔マクロファ ージの培養液中にマウス $\gamma-\mathrm{IFN}^{8}$ )9）（塩野義製 薬株式会社より供与）を $2 \times 10^{4} \sim 2 \times 10^{1} \mathrm{U} / \mathrm{m} l$ の濃度にそれぞれ培養開始より72時間，あるい は培養開始 4 日後から48時間混入した.

2. PA 活性の測定

1）発色合成基質を用いた 2 段階測定法

Coleman and Green ${ }^{10)}$ の方法を一部変更して 用いた. Deutsch and Mertz ${ }^{11)}$ の方法に準じ， リジンセファローズ・アフィニティーカラム法 を用い，犬血漿中より犬プラスミノーゲンを精 製した。マアロファージ培養上清を，PD-10

(Sephadex G-15M カラム，ファルマシア社) にて脱塩しこれをサンプルとした。 サンプルと $0.2 \mathrm{ng} / \mathrm{ml}$ 精製犬プラスミノーゲン，执よび $0.05 \mathrm{M}$ Glycine-buffer $(\mathrm{pH} 8.0)+0.1 \%$ Triton $\mathrm{X}-100+0.1 \%$ Gelatin とを，それぞれ 50 $\mu l$ ずつ等量混合し, $37^{\circ} \mathrm{C}$ にて 45 分間反応させ プラスミノーゲンの活性化を行った. その後50 $\mu l$ の $4 \mathrm{mM} \mathrm{S}-2251$ (Val-Leu-Lys-pNA) と $700 \mu l$ の $0.2 \mathrm{M}$ Phosphate-buffer (pH 7.4) $+0.2 \mathrm{M} \mathrm{NaCl}$ を加光, $37^{\circ} \mathrm{C}$ にて 30 分間反応さ せ，遊離した p-nitroaniline を $\mathrm{A}_{405}$ にて測定 した. Urokinase を用いたスタンダードカーブ を作製し，測定したPAをUrokinase 活性換 算値 $(\mathrm{U} / \mathrm{m} l)$ で表した.

2）エンザイモグラフィー 


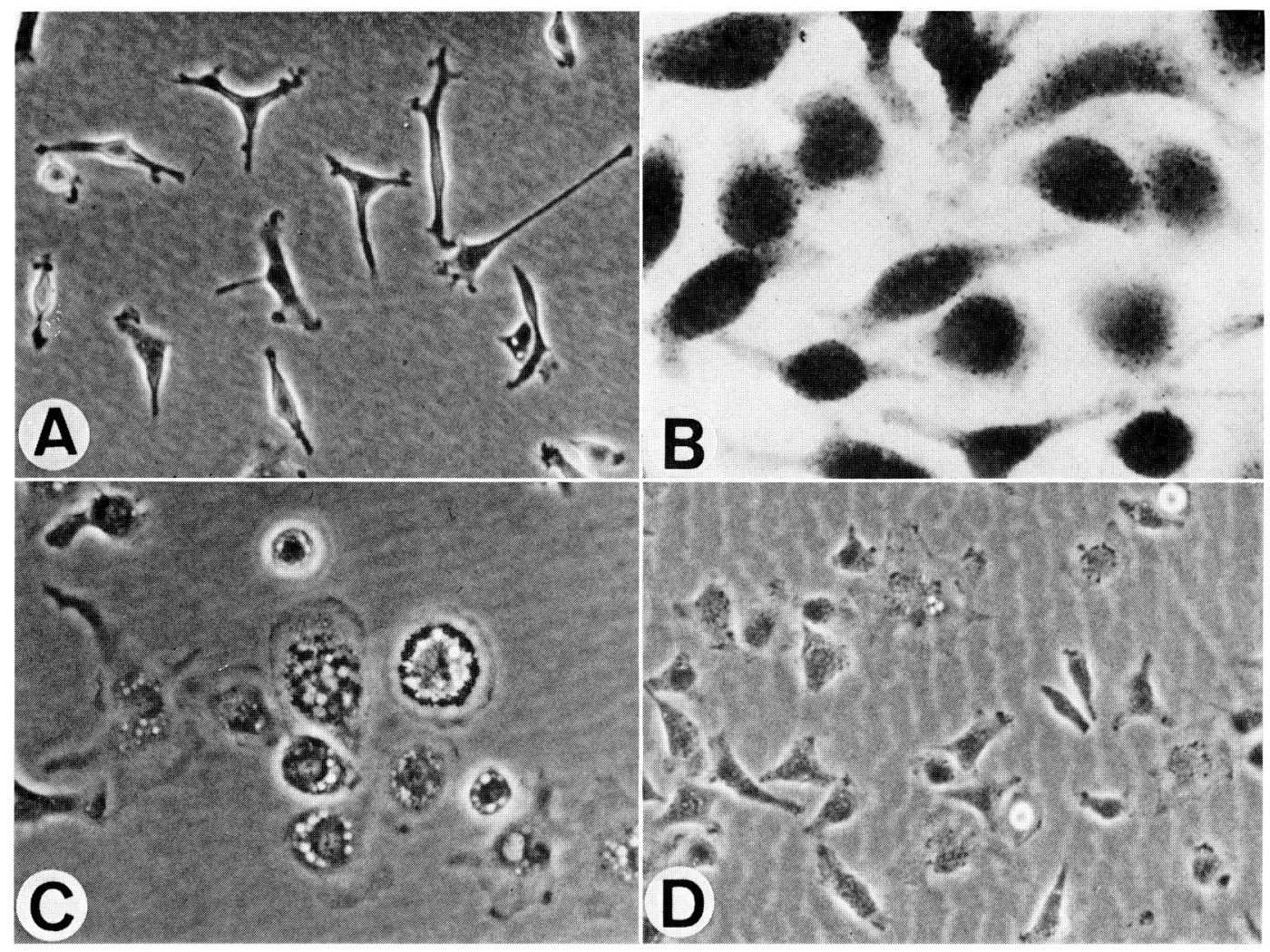

Fig. 1 Morphological feature of cultured macrophages. A) Phase contrast micrograms of cultured resident peritoneal macrophages at $72 \mathrm{~h}$ after removing non-adherent cells. B) Nonspecific esterase staining of resident peritoneal macrophages. C) Phase contrast micrograms of resident peritoneal macrophages after latex phagocytosis. D) Phase contrast micrograms of resident peritoneal macrophages after administration of lymphokines for 24 hours. Lymphokines were obtained from conditioned media of splenic cells cultured with sonicated M. lepraemurium for 48 hours.

酵素活性の分子量を決定するために, Heussen and Dowdle ${ }^{22)}$ の方法に準じ， $\alpha$-Casein を 基質としたェンザイモグラフィーを行った. すなわち, $1 \% \alpha$-Casein と $2.0 \mathrm{ng} / \mathrm{m} l$ 精製犬 プラスミノーゲンを混入したスラブゲル内にて SDS-PAGE を怙こない，泳動後ゲル内でプラ スミノーゲンの活性化と $\alpha$-Casein の分解を行 った。

\section{II. 成 績}

1）プラスチック付着細胞は，培養日数の経 過につれて細胞突起を他方向性に伸張させて次 第にマクロファージに特徵的な形態を示した

（図 1-A). 非特異的エステラーゼ染色にて, 細胞質内に赤褐色の顆粒状集塊が $98 \%$ 以上に認 められた（図 1-B）。ささらに，Latex 粒子の貪
食試験で $98 \%$ 以上の細胞に貪食が観察された (図 1-C).

2）常在性腹腔マクロファージの培養上清中 の PA 活性は, 培養初期飞扔いては約 $10^{-3} \mathrm{U} /$ $\mathrm{m} l$ の低い值を示したが，培養日数の経過につ れて上昇を示した（図 2-A）。エンザイモグラ フィーの結果, 常在性腹腔マクロファージの分 泌与るPA は, 主として分子量 48,000 の酵素 からなることが明らかになった（図 3-A）.

3）抗原刺激腹腔浸出マクロファージの分泌 する PA は, 約 $10^{-2} \mathrm{U} / \mathrm{m} l$ 以上の高い活性を 示した。これは，対照とした鼠らい菌感染マウ スに生食を腹腔内注射して得られた腹腔マク口 ファージ，あるいは非感染マウスに戍らい菌抗 原を腹腔内注射して得られた腹腔マクロファー ジの培息上清中に認められた PA 活性に比較し 


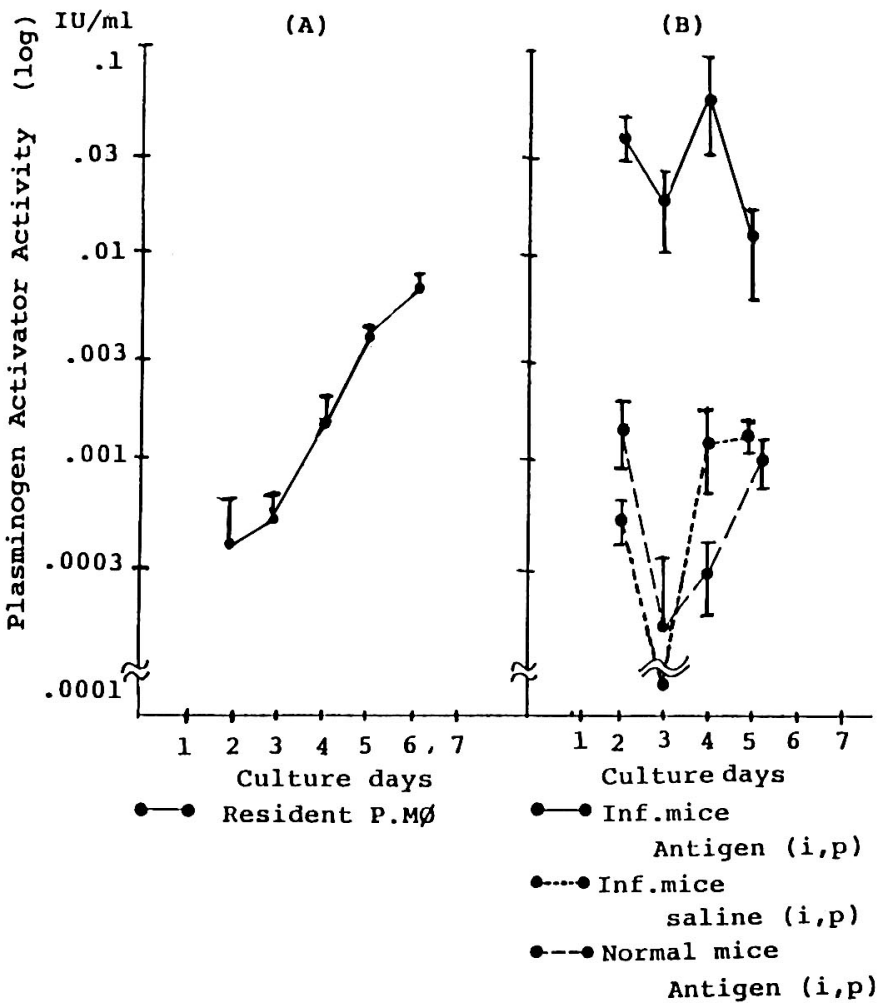

Fig. 2 PA activity secreted from cultured macrophages.

A) PA activity of resident peritoneal macrophages.

B) PA activity of peritoneal exudate macrophages by iniection (i. p.) of sonicated Mycobacterium lepraemurium to the infected mice (-) Control macrophages were obtained by injection of either sonicated M. lepraemurium to the non-infected mice ( $\cdots)$ ) or saline to the infected mice (...). Means \pm S.D. (bars) were showed.

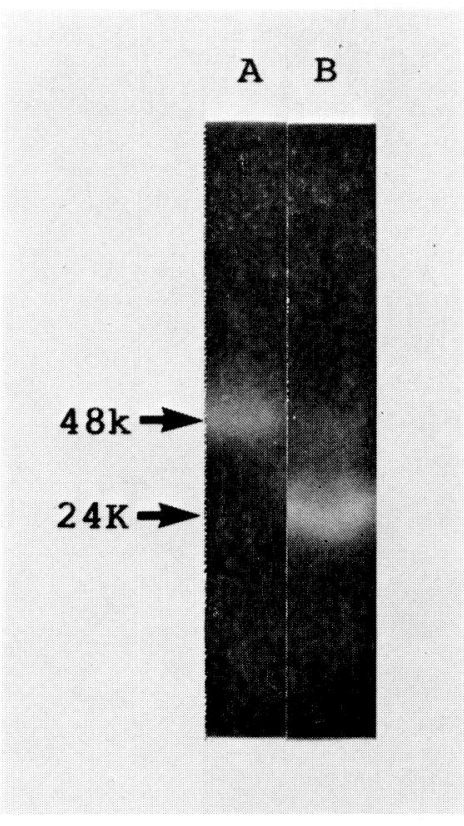

Fig. 3 Electrophoretic enzymographic pattren of $\mathrm{PA}$ from cultured macrophages. Effect of in vivo stimulation.

A) Resident peritoneal macrophages. B) Peritoneal exudate macrophages obtained by injection (i. p.) of sonicated M. lepraemurium to the infected mice.
て約 10〜100 倍の上昇であった（図 2-B). エンザイモグラフィーの結果, 抗原刺激腹腔、 クロファージの分泌する PAは，分子量 24,000 の酵素が主体で，分子量 48,000 の酵素はむし ろ弱く観察された（図 3-B).

4）リンフォカインの効果

常在性腹腔マクロファージの培養液中に, 培 責開始より24時間 $\mathrm{Ag}$-Lymphokine を混入した ところ，明らかなマクロファージの形態学的変 化が観察された（図 1-D）。このとさ培養上清 中の PA 活性は，対照に比して培盖 2 日目と 3 日目に抬いて有意に上昇していた（表 1 ）。土 ンザイモグラフィーの結果, 常在性腹腔マクロ ファージが，分子量 48,000のPA を主に分泌
する（図 4-A）のに対して, Ag-Lymphokine （図 4-B）あるいは Con A-Lymphokine（図 4-C）を混入した常在性腹腔マクロファージ は, 分子量 48,000 に加克分子量 24,000 の $\mathrm{PA}$ を分泌するよらになることが明らかになった。

5） マウス $\gamma$-IFN の効果

常在腹腔マクロファージの培養液中に $\gamma-$ IFN を，培養開始より72時間混入したところ，培養 上清中の PA 活性は，低下を示した（図 5-A）. しかしながら，常在性腹腔マクロファージを 4 日間培養した後に，48時間 $\gamma$-IFN を混入した ところ培養上清中の PA 活性は，最初の 24 時間 は急峻な上昇を示したが，続く24時間のらちに 低下を示した（図 5-B）.上昇時の培養上清中 
Table 1 Effect of in vitro stimulation on plasminogen activator of cultured macrophages.

\begin{tabular}{lll}
\hline Culture days & 2 days & 3 days \\
\hline $\begin{array}{l}\text { Mø*+ } \\
\text { culture supernatant of } \\
\text { Spleen cells }+\mathrm{Ag}^{* *}\end{array}$ & $3.56 \pm 3.38^{* * *}$ & $8.45 \pm 1.14$ \\
\hline $\begin{array}{l}\text { Mø } \\
\text { culture supernatant of } \\
\text { Spleen cells }\end{array}$ & $1.80 \pm 0.42$ & $6.34 \pm 0.84$ \\
\hline $\begin{array}{l}\text { Mø } \\
\text { * Mø; macrophages } \\
* * \text { sonicated M. lepraemurium suspension }\end{array}$ & \\
$* * *$ Means \pm S.D. (n=3) PA activity $\left(\mathrm{U} \times 10^{-3} / \mathrm{m} l\right)$
\end{tabular}

には,エンザイモグラフィーの結果，分子量 48,000 と 24,000 PA 活性が認められた（図 4-D).

\section{III. 考察}

マウスの慢性肉芽腫性炎の抽出液中に認めら れたPA は，分子量 24,000 の酵素が主体であ るここが報告されている113). 本研究は，常在 性腹腔マクロファージの分泌する PA が主に分 子量 48,000 であることを明らかにした．次に 腹腔内で瓦らい菌抗原を用いてマクロファージ をIn vivoに㧧いて免疫学的に刺激する実験を 行った結果，マクロファージの培息上清は高い PA 活性を示すようになり，同時に上清中に認 められたPAの分子量が変化し，これまで分子 量 48,000 のPA が主であったのが, 分子量 24,000のPAを主体とするよらになることを明 らかにした。

リンフォカイン (Ag-Lymphokine, Con ALymphokine) は, 培養常在性腹腔マクロファー ジを活性化し，その培盖液中に分子量 48,000 の PA に加光て分子量 24,000の PA \&出現する ようになることを, in vitro にて実験的に再現 した. 1978年 Gordon and Cohn ${ }^{14}$ は, BCG 感 染マウスを用い，T cell の分泌するファクター

(リンフォカイン) が，マクロファージの分泌 する PAの活性を著明に上昇させることを報告 している. 本研究では, PA 活性の上昇のみな らず分泌される PAの分子量変化を明らかにし

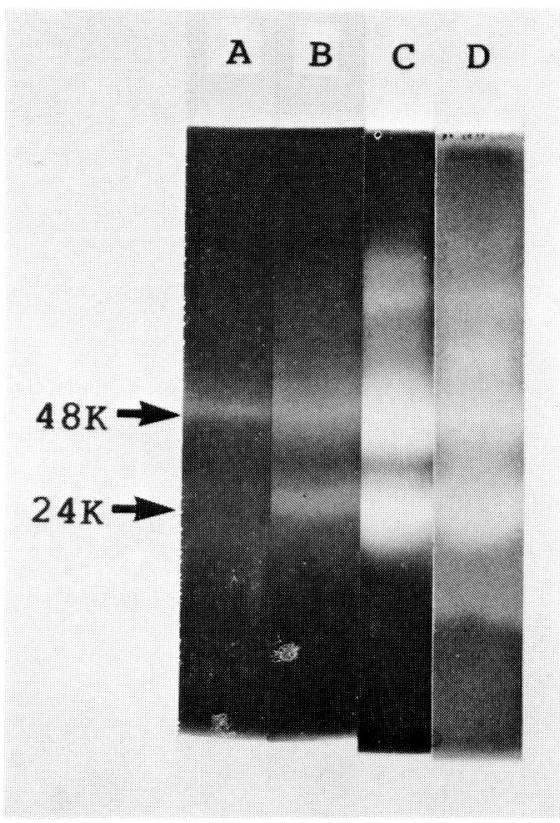

Fig. 4 Electrophoretic enzymographic pattren of PA from cultured macrophages. Effect of in vitro stimulation.

A) Resident peritoneal macrophages. B) Effect of $\mathrm{Ag}-$ Lymphokines. Ag-Lymphokines were prepared from conditioned media of cultured splenic cells with M. lepraemurium. C) Effect of Con ALymphokines. Con A-Lymphokines were prepared from conditioned media of cultured splenic $\mathrm{T}$ cells with $5 \mu \mathrm{g} / \mathrm{ml}$ Concanavalin A. D) Effect of mouse recombinant $\gamma$-IFN. 


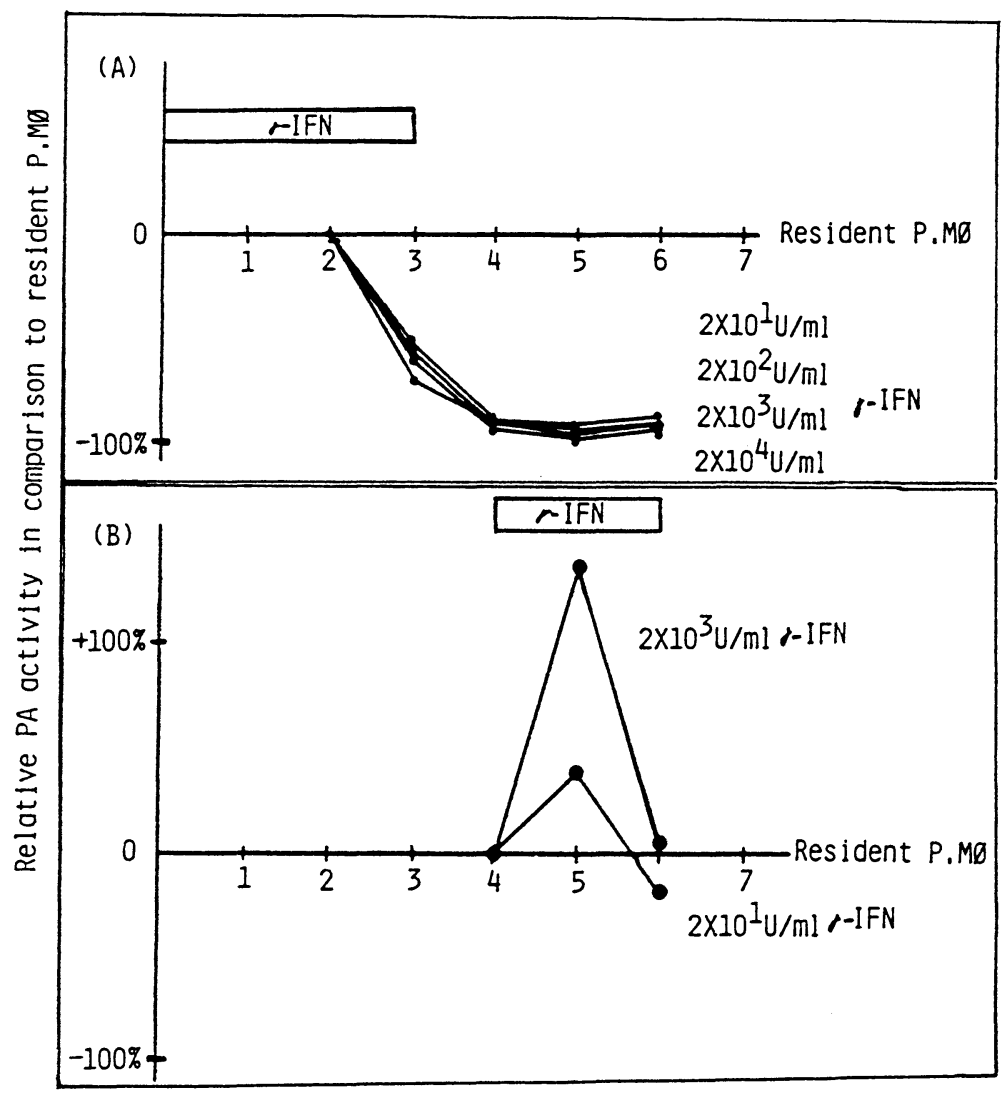

Culture days

Fig. 5 Effect of $\gamma$-IFN on cultured macrophages. Relative PA activity in comparison to resident peritoneal macrophages was expressed as $\%$ activity.

A) After removing non-adherent cells, $\gamma$-IFN was added for 072 bours. B) $\gamma$-IFN was added after 4 days of cultuer for the subsequent 48 hours.

た.しかしながらリンフォカインに含まれる主 要なマクロファージ活性化因子すなわち $\gamma$ IFNを培養マクロファージに最初の24時間加兄 たところ，かえってPA 分泌を阻害する結果が 得られた。それに対し 4 日間培養を続けたのち に $\gamma$-IFN を投与することにより常在性腹腔マ クロファージ培養上清中の PA 活性は上昇し た. 従って, $r$-IFN の働く前段階として粘着 等によりマクロファージを部分的に活性化し $\gamma$-IFN に対する反応性が獲得されたと解釈さ れた. マクロファージの段階的活性化に関して は, Ruco and Meltzer ${ }^{15) 16)}$ は, 腫瘍細胞傷害効
果，あるいは活性酸素産生の系に打いて同様の ことを報告している，本研究では， $\gamma$-IFN は， マクロファージのPA 分泌に対するリンフォカ インの作用を部分的に再現した。

PA には, Urokinase-type ${ }^{17)}$ と tissue-type ${ }^{18)}$ とがあることが報告されている。 ヒトの単球／ マクロファージが，無刺激の条件で分泌する PA は, Urokinase-type であることが Saksela 等 ${ }^{199}$ により報告されて拈り，またマウスの Urokinase の分子量が 48,000 であることが Belin 等 ${ }^{20}$ によって報告された. したがって本研究で みられたマウスマクロファージの分泌する分子 
量 48,000のPA は, マウスの Urokinase と同 一の物質である可能性が高い，ヒト単球/マク ロファージを用いた研究で, Stepens and Gol$\operatorname{der}^{211}$ は, 単球/マクロファージの分泌する PA 活性がリンフォカイン等の刺激により上昇し, この時分泌されるPA の性質が変化することを 報告している。 ヒト Urokinase が分子量55,000 と33,000の二つの酵素からなり, 分子量 33,000 の酵素は, 分子量55,000の酵素がプラスミン等 のトリプシン様セリン酵素により限定分解を受 けたものであることが報告されている22223)。こ の事より, マウスマクロファージの分泌する分 子量 24,000 の PA は分子量 48,0000の PA の限定分解産物である可能性が最も高いと著者 は考学ている. 今後この二つの酵素の, 抗原 性, フィブリン親和性, 基質特異性等を検討す る必要があると考学る。

\section{文献}

1) Izaki, S., Hibino, T., Hsu, P.S., Izaki, M. and Matuo, O.: Plasminogen activator and plasminogen activator inhibitor associated with granulomatous inflammation: A study with murine leprosy. Thromb. Haemostas., 52: 243 $\sim 249,1984$.

2) Unkeless, J.C., Gordon, S. and Reich, E.: Secretion of plasminogen activator by stimulated macrophages. J. Exp. Med., 139; 834 850, 1974.

3) Sonozaki, H. and Cohen, S.: The macrophage disappearance reaction: Mediation by a soluble lymphocyte-derived factor. Cell. Immunol., 2; 341 376, 1971.

4) Yam, L.T., Li, C.Y. and Crosby, W.H.: Cytochemical identification of monocytes and granulocytes. Amer. J. Clin. Pathol., 55; 283 $\sim 290,1971$.

5) Cohn, Z.A. and Benson, B.: The differentiation of mononuclear phagocytes. J. Exp. Med., 121; 153 169, 1964.

6) Dumonde, D.C., Wolstencroft, R.A., Panayi, G.S., Matthew, M., Moley, J. and Howson, W.T.: "Lymphokines": Non-antibody mediators of cellular immunity generated by lymphocyte activation. Nature, 224; 38 42,
1969.

7) Julius, M.H., Simpson, E. and Herzenberg, L.A.: A rapid method for the isolation of functional thymus-derived murine lymphocytes. Eur. J. Immunol., 3; 645 649, 1973.

8) Roberts, K.W. and Vasil, A.: Evidence for the identity of murine gamma interferon and macrophage activating factor. J. Interferon Res., 2; 519 532, 1982.

9) Havell, E.A. and Spitalny, G.L.: Two molecular weight species of murine gamma interferon. Virology, 129; 508 513, 1983.

10) Coleman, P.L. and Green, G.D.J.: A coupled photometric assay for plasminogen activtor. Methods in Enzymoloy, 80; 408 414, 1981.

11) Deutsch, D.G. and Mertz, E.T.: Plasminogen: Purification from human plasma by affinity chromatography. Science, 170; 1095 1096, 1970.

12) Heussen, C. and Dowdle, E.B.: Electrophoretic analysis of plasminogen activators in polyacrylamide gels containing sodium dodecyl sulfate and copolymerized substrates. Anal. Biochem., 102; 196 202, 1980.

13) Izaki, S., Hornbeck, L., Higuchi, M., Fukuyama, K., Epsrein, W.L., Tokairin, S. and Matsuo, O.: Detection of granuloma-associated plasminogen activator in experimental murine shistosomiasis. Exp. Mol. Path., 43; 82 89, 1985.

14) Gordon, S. and Cohn, Z.A.: Bacille Calmette -Guerin infection in the mouse. J. Exp. Med., 147; 1175 1187, 1978.

15) Ruco, L.P. and Meltzer, M.S.: Macrophage activation for tumor cytotoxicity: Development of macrophage cytotoxic activity requires completion of a sequence of short-lived intermediary reactions. J. Immunol., 121; 2035 2042, 1978.

16) Ruco, L.P. and Meltzer, M.S.: Macrophage activation for tumor cytotoxicity: Induction of tumoricidal macrophages by supernatants of PPD-stimulated Bacillius Calmette-Guerin immune spleen cell cultures. J. Immunol., 119; 889 896, 1977.

17) White, W.F., Barlow, G.H. and Mozen, M. 
M.: The isolation and characterization of plasminogen activator (urokinase) from human urine. Biochemistry, 5; 2160 2169, 1966.

18) Rijken, D.C. and Collen, D.: Purification and characterization of the plasminogen activator secreted by human melanoma cells in culture.

J. Biol. Chem., 256; 7035 7041, 1981.

19) Saksela, O., Hovi, T. and Vaheri, A.: Urokinase-type plasminogen activator and its inhibitor secreted by cultured human monocyte -macrophages. J. Cell. Physiol., 122; 125 $132,1985$.

20) Belin, D., Vassalli, J-D., Combepine, C., Godeau, F., Nagamine, Y., Reich, E., Kocher, H.P. and Duvoisin, R.M. : Cloning, nucleotide sequencing and expression of cDNA sencoding mouse urokinase-type plasminogen activator. Eur. J. Biochem., 148; 225 232, 1985.

21) Stephens, R.W. and Golder, J.P.: Novel propertier of human monocyte plasminogen activator. Eur. J. Biochem., 139; 253 258, 1984.

22) Soberano, M.E., Ono, E.B. and Johnson, A. J.: The effect of inhibitors on the catalytic conversion of urokinase. Thromb. Res., 9; 675 681, 1976.

23) Barlow, G.H., Francis, C.W. and Marder, V. J.: On the conversion of high molecular weight urokinase to the low molecular weight form by plasmin. Thromb. Res., 23; 541 547, 1981.

\section{○内科疾患のカルシウし代謝とその異常}

\section{力ル
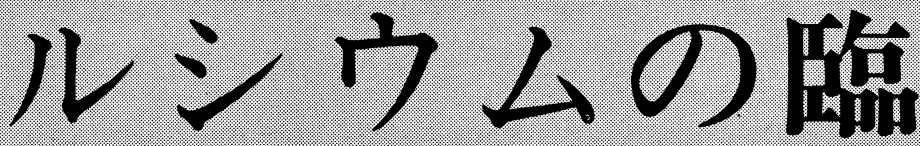

編集 神戸大学内科教授 藤田拓男 専門医 15氏分担執筆 B 5 判 365頁 図129 表78 定価9,800円（干350円）

カルシウムは人体のあらゆるところに存在し、あらゆる機能に関与する。したが って、内科疾患のすべてに密接に関連しており、内科学を理解するためにカルシウ 厶代謝とその異常をまず知らなければならない。本書は内科疾患のあらゆる部分に わたってカルシウムの影を探し求め、カルシウムの臨床を通して内科学を再構成し ようとしたユニークかつ野心的な試みの産物である。

内容：総 論, 第 1 章 神経系疾患とカルシウム代謝異常, 第 2 章 心血管疾患とカルシウム, 第 3 章 腎疾患とカルシウム, 第 4 章 呼吸器疾患とカルシウム, 第 5 章 消化器疾患とカルシ ウム, 第 6 章 血液疾患とカルシウム, 第 7 章 内分泌疾患とカルシウム, 第 8 章 リウマチ様 関節炎とカルシウム代謝, 第 9 章 膠原病および免疫アレルギ一疾患とカルシウム, 第10章 物 理的原因による疾患とカルシウム, 第11章 薬剤とカルシウム代謝異常, 第12章 老年病とカル シウム, 第13章 覀性腫瘍とカルシウム, 第14章 カルシウム代謝検査法, 索 引 